\title{
Selection of an Appropriate Pre-Injection Pattern in a Marine Diesel Engine Through a Multiple-Criteria Decision Making Approach
}

\author{
María Isabel Lamas Galdo ${ }^{1, *(\mathbb{D})}$, Laura Castro-Santos ${ }^{1}$ (1) and Carlos G. Rodríguez Vidal ${ }^{2}$ \\ 1 Escola Politécnica Superior, Universidade da Coruña, 15403 Ferrol, Spain; laura.castro.santos@udc.es \\ 2 Norplan Engineering S.L., 15570 Naron, Spain; c.rodriguez.vidal@udc.es \\ * Correspondence: isabellamas@udc.es; Tel.: +34-881013896
}

Received: 18 March 2020; Accepted: 31 March 2020; Published: 4 April 2020

\begin{abstract}
In the present work, a numerical model was developed to analyze a commercial diesel engine. The adequacy of this model was validated using experimental results. This model was employed to study several pre-injection strategies. Particularly, the pre-injection rate, duration and starting instant were analyzed in the ranges $5 \%$ to $25 \%, 1^{\circ}$ to $5^{\circ}$ and $-22^{\circ}$ to $-18^{\circ}$, respectively. The effect on consumption and emissions of $\mathrm{NO}_{x}, \mathrm{CO}$, and $\mathrm{HC}$ wereas evaluated. Since some of these configurations have opposite effects on consumption and/or emissions, it is necessary to develop a formal tool to characterize the most appropriate injection pattern. To this end, a multiple-criteria decision making approach was employed. It was found that the injection duration must remain as low as possible due to significant reductions in $\mathrm{NO}_{\mathrm{x}}$. The most appropriate injection pattern resulted $1^{\circ}$ pre-injection duration, $20 \%$ pre-injection rate, and $-19^{\circ}$ pre-injection starting instant. This configuration leads to increments of $6.7 \%$ in consumption, $3.47 \%$ in CO, and $3.83 \%$ in $\mathrm{HC}$ but reduces $\mathrm{NO}_{x}$ by $34.67 \%$ in comparison with the case without pre-injection.
\end{abstract}

Keywords: MCDM; CFD; engine; emissions; consumption

\section{Introduction}

It is well known that diesel engines are efficient thermal machines but emit significant levels of harmful gases such as $\mathrm{CO}_{2}$, Particulate Matter (PM), $\mathrm{NO}_{x}, \mathrm{CO}, \mathrm{HC}$ and $\mathrm{SO}_{\mathrm{x}}$ [1]. Between these, $\mathrm{PM}$ and $\mathrm{NO}_{\mathrm{x}}$ are especially important in diesel engines. Smoke emissions, related to PM, mostly composed of soot, are related to several diseases but are not globally regulated [2]. On the other hand, ever increasing $\mathrm{NO}_{\mathrm{x}}$ emission limits have been imposed by regional and international authorities [3]. According to this, several procedures have been developed in the recent years to reduce $\mathrm{NO}_{\mathrm{x}}$ emissions in diesel engines such as EGR, water injection, modification of the injection parameters and after-treatments [4-7]. Between these measurements, this paper focuses on multiple injection strategies using pilot injections. This strategy affects mixing and combustion [8]. Several works about the advantages and disadvantages of pilot injections can be found in literature. One of the main disadvantages is that soot can increase because pilot injections aggravate spray characteristics and particulates can be formed at the rich region $[9,10]$. In order to avoid this problem, some authors recommend combining multiple injections with other systems such as EGR [11] or high injection pressures [12], while other researchers indicate that it is possible to obtain both $\mathrm{NO}_{x}$ and particulate reduction using only multiple injections. In this regard, Carlucci et al. [13] analyzed the pilot injection timing and duration and found that $\mathrm{NO}_{\mathrm{x}}$ emission levels are mainly influenced by the pilot duration, whereas smoke emission is influenced by both variables. Tanaka et al. [14] analyzed the time and quantity of the pilot injection. Benajes et al. [15] analyzed the effect of the dwelling time, i.e., the time between two consecutive injections, obtaining reductions 
in noise, $\mathrm{NO}_{x}$ and particulates. Pierpont et al. [16] varied the fuel distribution in each pulse and the dwelling time between pulses and obtained a reduction in $\mathrm{NO}_{\mathrm{x}}$ and particulates but also a $3 \%-4 \%$ increase in consumption. Hotta et al. [17] analyzed the number of pre-injections and obtained reductions in both $\mathrm{NO}_{x}$ and $\mathrm{HC}$. Fang et al. [18] analyzed the effect of the injection angle when using multiple injections. Other works such as those of Ishida et al. [19] and Minani et al. [20] obtained $\mathrm{NO}_{x}$ and consumption reductions but recommended employing a small amount of pilot quantity in order to maintain soot emissions. In addition to these aforementioned works based on diesel engines, other similar studies were realized using biodiesel [21], gasoline [22-24], dual fuel [25-28] and other fuels [29-34].

Numerical simulations also provide interesting information to analyze multiple injections. Particularly, in the field of Computational Fluid Dynamics (CFD), one can refer to the work of Lechner et al. [35], who analyzed advanced injection strategies to achieve partially premixed combustion in a diesel engine; Sun and Reitz [36], who analyzed injection strategies to optimize two-stage combustion; Verbiezen et al. [37], who analyzed the effect of injection timing; Zehni and Jafarmadar [38], who analyzed the effect of split injection in a direct-injection diesel engine; Abdullah et al. [39], who analyzed the effect of injection pressure; Coskun et al. [40], who analyzed second injection timings; Wang et al. [41], who analyzed several fuel injection strategies on a gasoline engine; Zhaojie et al. [42], who analyzed two-stage fuel injection with EGR; Lamas et al. [43,44], who analyzed several configurations of pilot injections; and Sencic [45], who analyzed alternative injection patterns.

Despite this literature about multiple injections, it is important to develop a reliable tool to characterize the most appropriate injection pattern. In this regard, this work presents a Multiple-Criteria Decision Making (MCDM) approach to characterize the most appropriate injection pattern. MCDM methodologies constitute a formal tool to handle complex decision-making situations, providing coherence in the decision process. Three pre-injection parameters such as pre-injection rate $(\mathrm{R})$, duration (D) and starting instant (S) were analyzed. The emissions and consumption analyzed in the present work were obtained through a CFD model previously validated with experimental results.

\section{Materials and Methods}

The engine analyzed in the present work is the Wärtsilä $6 \mathrm{~L} \mathrm{46.} \mathrm{This} \mathrm{is} \mathrm{a} \mathrm{four-stroke} \mathrm{diesel} \mathrm{engine}$ with six cylinders. Each cylinder presents two intake and two exhaust valves. The fuel injector has 10 holes and is placed at the center of the cylinder head. The fuel is injected directly into the cylinder since it is a direct injection engine.

The geometry and mesh were realized using SolidEdge and Gambit softwares, respectively. A grid independence study was carried out to provide its adequacy. The software OpenFOAM was employed for the CFD simulations. OpenFOAM was chosen because it is an open software which allows a complete manipulation of the code. The simulation started at $360^{\circ}$ Crank Angle After Top Dead Center (CA ATDC) and the whole cycle was analyzed. As boundary conditions, the heat transfer from the cylinder was modelled as a combined convection-radiation. The RANS (Reynolds-averaged Navier-Stokes) equations of conservation of mass, momentum and energy were solved. The k- $\varepsilon$ was employed as the turbulence model due to its robustness and reasonably accuracy for a wide range of turbulent flows. As fuel droplet breakup, the Kelvin-Helmholtz and Rayleigh-Taylor breakup models [46] were employed, and the Dukowicz model [47] for the heat-up and evaporation. Regarding the chemical kinetics, a reaction mechanism was programmed by combining the following three kinetic schemes:

- Ra and Reitz's [48] kinetic scheme, based on 131 reactions and 41 species, for combustion.

- Yang et al.'s [49] kinetic scheme, based on 20 species and 43 reactions, for $\mathrm{NO}_{\mathrm{x}}$ formation.

- Miller and Glarborg's [50] kinetic scheme, based on 24 species and 131 reactions, for $\mathrm{NO}_{\mathrm{x}}$ reduction.

This numerical model was validated using experimental measurements. For this purpose, experimental measurements obtained elsewhere [51-55] were employed. The emissions and Specific 
Fuel Consumption (SFC) obtained numerically and experimentally at several loads are indicated in Figure 1. This figure shows a reasonable correspondence between numerical and experimental results. The in-cylinder pressure obtained numerically and experimentally at $100 \%$ load is shown in Figure 2. This figure also shows a satisfactory correspondence between experimental and numerical results. A certain error was inevitable due to both numerical and experimental handicaps. On the one hand, the instruments employed to characterize experimental measurements have a certain tolerance and, on the other hand, numerical errors are introduced due to the discretization processes and the hypothesis assumed to simplify the governing equations.

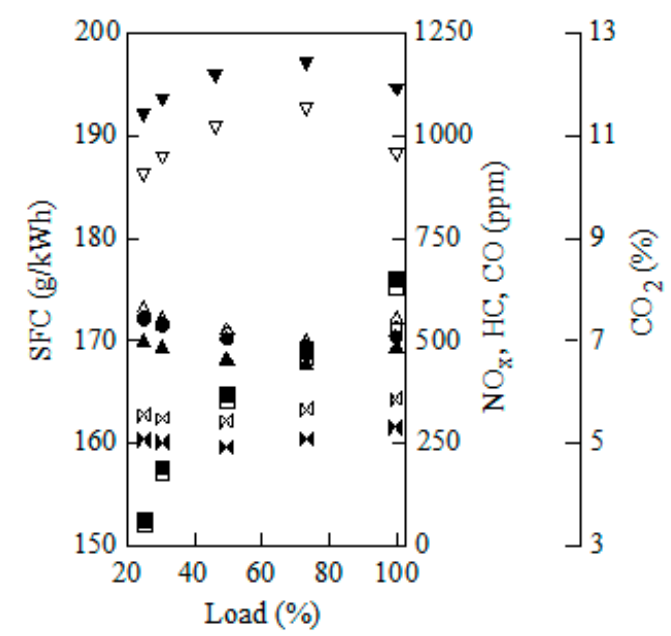

- SFC, experimental

- $\mathrm{NO}_{\mathrm{x}}$, experimental

^ $\mathrm{HC}$, experimental

$\mathrm{CO}$, experimental

- $\mathrm{CO}_{2}$, experimental

o SFC, numerical

$\nabla \mathrm{NO}_{\mathrm{X}}$, numerical

$\triangle \mathrm{HC}$, numerical

M CO, numerical

$\square \mathrm{CO}_{2}$, numerical

Figure 1. SFC and emissions numerically and experimentally obtained at different loads.

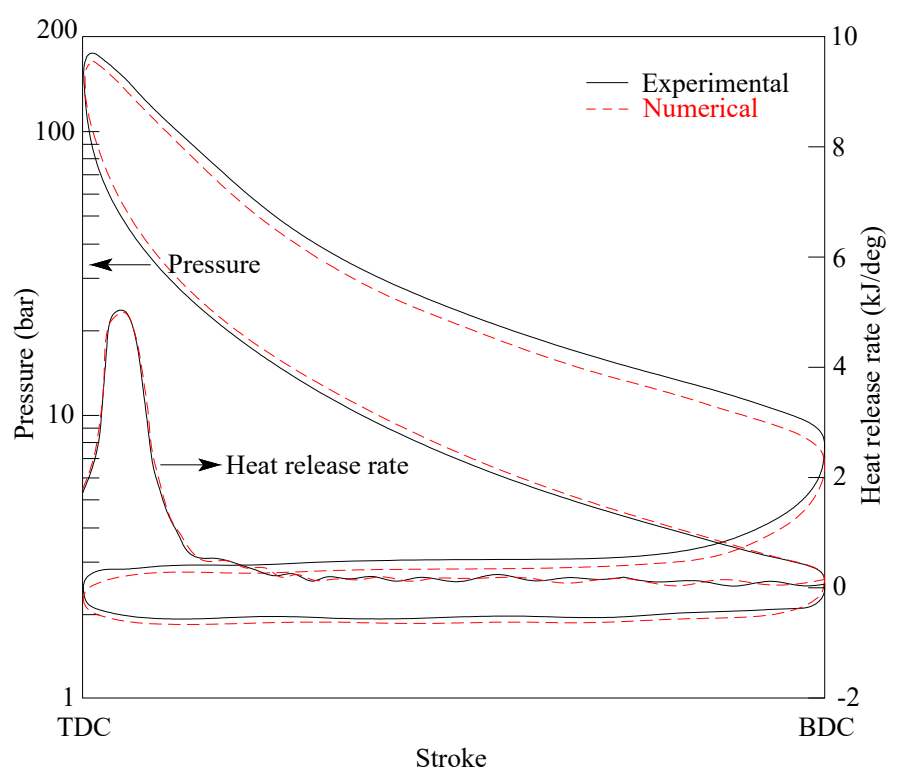

Figure 2. In-cylinder pressure numerically and experimentally obtained, 100\% load.

\section{Results and Discussion}

Once the numerical model was validated with experimental measurements, it was used to analyze the results of several pre-injection patterns. Five pre-injection rates were employed: $5 \%, 10 \%, 15 \%$, $20 \%$ and $25 \%$; five pre-injection durations: $1^{\circ}$ Crank Angle (CA), $2^{\circ} \mathrm{CA}, 3^{\circ} \mathrm{CA}, 4^{\circ} \mathrm{CA}$ and $5^{\circ} \mathrm{CA}$; and five pre-injection starting instants: $-22^{\circ} \mathrm{CA}$ ATDC, $-21^{\circ} \mathrm{CA}$ ATDC, $-20^{\circ} \mathrm{CA}$ ATDC, $-19^{\circ} \mathrm{CA}$ ATDC and $-18^{\circ} \mathrm{CA}$ ATDC. These ranges were chosen according to a previous paper [43], in which it was obtained that wider ranges lead to excessive increments in $\mathrm{NO}_{\mathrm{x}}$ emissions or consumption. Taking into account these values of pre-injection rates, durations and starting instants, a total of 
125 cases were analyzed. These are summarized in Figure 3. SFC and emissions of $\mathrm{NO}_{\mathrm{x}}, \mathrm{CO}$ and $\mathrm{HC}$ were characterized for these 125 cases.

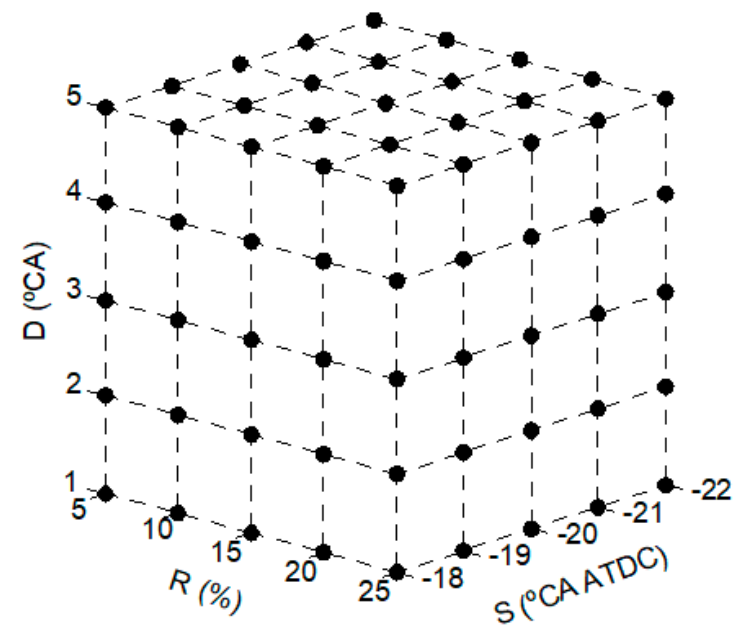

Figure 3. Schematic representation of the cases analyzed.

As indicated previously, a MCDM method was employed. The first step in MCDM approaches consists on defining the decision tree with the relative importance of each parameter, Table 1 . Two requirements (general aspects) were considered: consumption and emissions. The second level represents the sub-requirements (specific aspects). The relative importance of each requirement and sub-requirement must be defined too. In the present work, this importance was distributed equally, i.e., the same importance was given to SFC and emissions: $50 \%$ ( $\alpha=0.5$ in per unit basis) for each one. Regarding emissions, the same importance was given to $\mathrm{NO}_{\mathrm{x}}, \mathrm{CO}$ and $\mathrm{HC}: 33.3 \%(\beta=0.333$ in per unit basis) for each one. It is worth mentioning that other scenarios could also be possible in case it is necessary to provide other levels of importance.

Table 1. Decision tree for the MCDM approach.

\begin{tabular}{cc}
\hline Requirement & Sub-Requirement \\
\hline SFC (50\%) & $\mathrm{SFC}(100 \%)$ \\
& $\mathrm{NO}_{\mathrm{x}}(33.3 \%)$ \\
Emissions (50\%) & $\mathrm{CO}(33.3 \%)$ \\
& $\mathrm{HC}(33.3 \%)$ \\
\hline
\end{tabular}

The next step was to calculate the variation of each sub-requirement respect to the case without pre-injection, in per unit basis, Equation (1).

$$
V_{i}=\frac{X_{i}-X_{r e f}}{X_{r e f}}
$$

where $X_{i}$ is the value of the sub-requirement $i$ and $X_{\text {ref }}$ the value corresponding to the case without pre-injection, i.e., $\mathrm{SFC}=172 \mathrm{~g} / \mathrm{kWh}, \mathrm{NO}_{\mathrm{x}}=13.3 \mathrm{~g} / \mathrm{kWh}, \mathrm{CO}=4.5 \mathrm{~g} / \mathrm{kWh}$ and $\mathrm{HC}=5.5 \mathrm{~g} / \mathrm{kWh}$. Once each indicator was transformed into its variation in per unit basis, the global adequacy index, $A I$, was computed by Equation (2).

$$
A I=\sum_{i=1}^{125} \alpha_{i} \beta_{i} V_{i}
$$

where $\alpha_{i}$ is the weight of each requirement and $\beta_{i}$ the weight of each sub-requirement in per unit basis.

The minimum value of the $A I$ is the most adequate solution. It was determined using an in-house code programmed using the open software GNU Octave. For the parameters analyzed in the present 
work, the minimum $A I$ is -0.0122 , corresponding to $-19^{\circ}$ CA ATDC pre-injection starting instant, $20 \%$ pre-injection rate and $1^{\circ} \mathrm{CA}$ pre-injection duration. The results are detailed in Appendix A. As can be seen in this appendix, the minimum $A I$ value was obtained in the ninety-first case analyzed. On a per-unit basis, SFC varies by $0.067 ; \mathrm{NO}_{\mathrm{x}}-0.3467, \mathrm{CO} 0.0347$ and $\mathrm{HC} 0.0383$, corresponding to an SFC increment of SFC 6.7\%; $\mathrm{NO}_{\mathrm{x}}$ reduction of $34.7 \%$, CO increment of $3.47 \%$ and $\mathrm{HC}$ increment of $3.83 \%$ in comparison with the case without pre-injection. Despite the increments in SFC, CO and HC, these solution results are the most appropriate because the increments are low and the $\mathrm{NO}_{\mathrm{x}}$ reduction is too significant.

The results shown in Appendix A indicate that the influence of $\mathrm{CO}$ and $\mathrm{HC}$ in the $A I$ is not too important due to the low variation of these emissions with the pre-injection rate, duration and starting instant. On the other hand, SFC and $\mathrm{NO}_{\mathrm{x}}$ emissions are more sensitive. A representative quantity of pre-injection is necessary, specifically $20 \%$, due to the important reduction on $\mathrm{NO}_{\mathrm{x}}$ emissions. Nevertheless, if this pre-injection rate is increased, it leads to important increments in SFC and, to a lesser extent, $\mathrm{CO}$ and $\mathrm{HC}$ emissions. Regarding the pre-injection instant, early pre-injections are appropriate to reduce $\mathrm{NO}_{x}$ but the increase increment in SFC is considerable; for this reason, a $-19^{\circ} \mathrm{CA}$ ATDC was obtained. Finally, the injection duration mainly affects to $\mathrm{NO}_{\mathrm{x}}$ and short injections lead to considerable $\mathrm{NO}_{\mathrm{x}}$ reductions. The goal of $\mathrm{NO}_{\mathrm{x}}$ reduction using pre-injections is to control the combustion temperature. It is well known that high combustion temperatures promote $\mathrm{NO}_{\mathrm{x}}$ formation [56]. In order to control the combustion temperature, it is necessary to rigorously inject the fuel at the optimum instant. It is worth mentioning that in practical applications it is not possible to reduce the injection duration at the desirable level. For instance, the present engine is a four-stroke medium-speed model which runs at $500 \mathrm{rpm}$, which corresponds to $0.00033 \mathrm{~s}$ to reach $1^{\circ}$ CA. Some current piezo-injectors are able to switch on and off in tens of microseconds but solenoid or electromagnetic injectors have longer response times. For this reason, pre-injections shorter than $1^{\circ} \mathrm{CA}$ were not analyzed in the present work. Using $1^{\circ} \mathrm{CA}$ pre-injection duration, the $A I$ is represented in Figure 4 . As can be seen, the minimum value of $A I,-0.0122$ is reached using $20 \%$ pre-injection rate and $-19^{\circ}$ CA ATDC pre-injection starting instant, as indicated above.

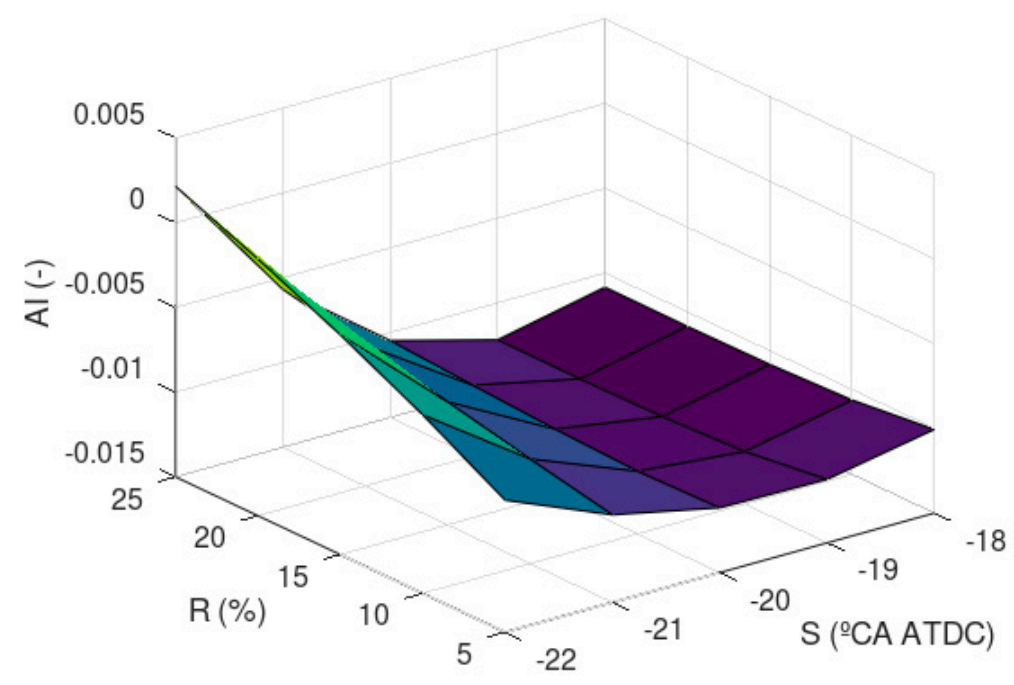

Figure 4. $A I$ against $R$ and $S$. Pre-injection duration $1^{\circ} \mathrm{CA}$.

The consumption against the pre-injection rate and starting instant is shown in Figure 5. This figure refers to $1^{\circ} \mathrm{CA}$ pre-injection duration. As can be seen, early pre-injections promote considerable increase increments in SFC, as indicated above. On the other hand, the pre-injection rate also promotes increase increments in SFC considerably. 


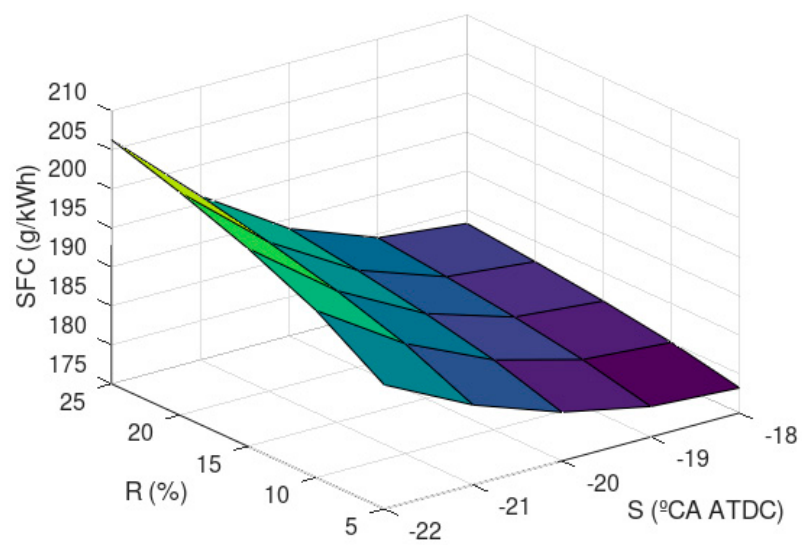

Figure 5. SFC against $R$ and $S$. Pre-injection duration $1^{\circ} \mathrm{CA}$.

$\mathrm{NO}_{\mathrm{x}}$ emissions against the pre-injection rate and starting instant are indicated in Figure 6. This figure refers to $1^{\circ} \mathrm{CA}$ pre-injection duration. As can be seen, early pre-injections promote reductions in $\mathrm{NO}_{\mathrm{x}}$, but increment $\mathrm{SFC}$, as indicated above. On the other hand, the pre-injection rate considerably reduces $\mathrm{NO}_{\mathrm{x}}$ but also increments SFC.

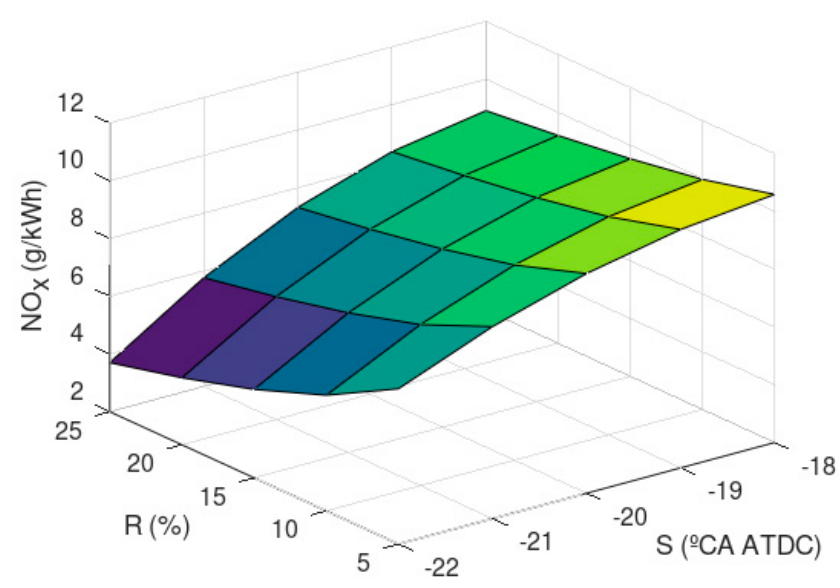

Figure 6. $\mathrm{NO}_{\mathrm{x}}$ against $R$ and $S$. Pre-injection duration $1^{\circ} \mathrm{CA}$.

Figures 7 and 8 show the $\mathrm{CO}$ and $\mathrm{HC}$ emissions against the pre-injection rate and starting instant. These figures refer to $1^{\circ} \mathrm{CA}$ pre-injection duration. As can be seen, both $\mathrm{CO}$ and $\mathrm{HC}$ are sensitive to the pre-injection rate and starting instant. Nevertheless, the influence of $\mathrm{CO}$ and $\mathrm{HC}$ in the results is low due to their low variation.

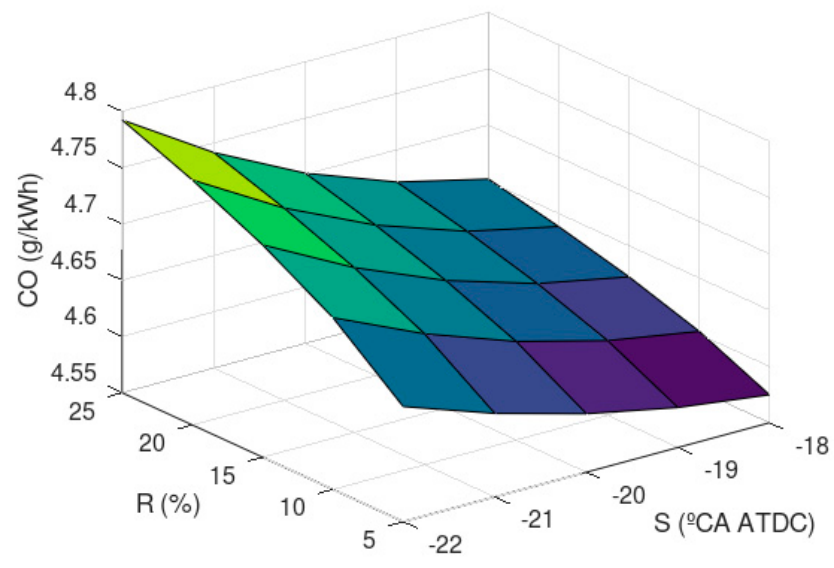

Figure 7. $\mathrm{CO}$ against $R$ and $S$. Pre-injection duration $1^{\circ} \mathrm{CA}$. 


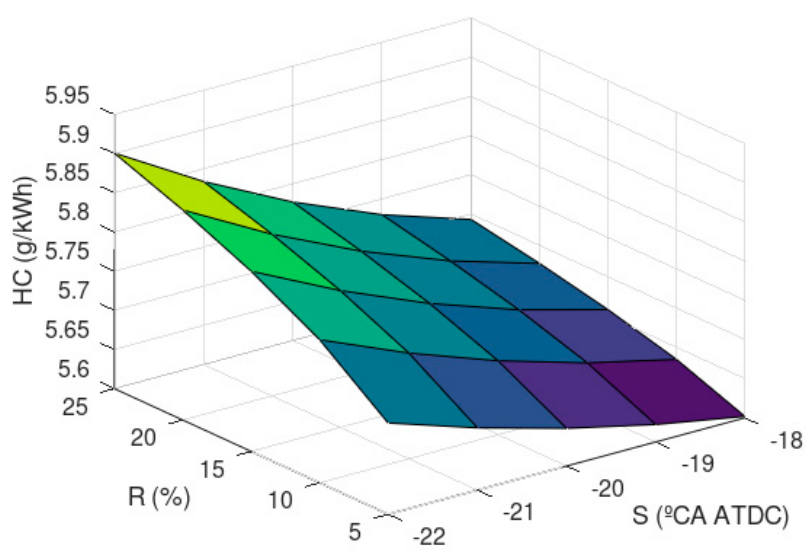

Figure 8. HC against $R$ and $S$. Pre-injection duration $1^{\circ} \mathrm{CA}$.

\section{Conclusions}

The present work proposes a numerical model to analyze the commercial diesel engine Wärtsilä $6 \mathrm{~L} 46$. Once validated, the numerical model was employed to analyze 125 injection patterns with different values of pre-injection rate, duration and starting instant in the ranges $5 \%$ to $25 \%, 1^{\circ} \mathrm{CA}$ to $5^{\circ} \mathrm{CA}$ and $-22^{\circ} \mathrm{CA}$ ATDC to $-18^{\circ} \mathrm{CA}$ ATDC, respectively. Due to this large number of results and the fact that these parameters can lead to different and opposite effects, it is difficult to determine the most adequate injection pattern. According to this, a MCDM approach was employed to select the most appropriate injection pattern. The effects on consumption and emissions of $\mathrm{NO}_{\mathrm{x}}, \mathrm{CO}$ and $\mathrm{HC}$ were characterized. It was found that the injection duration must remain as lower as possible due to significant reductions in $\mathrm{NO}_{\mathrm{x}}$. The most appropriate injection pattern was shown in the $1^{\circ}$ CA pre-injection duration, $20 \%$ pre-injection rate and $-19^{\circ} \mathrm{CA}$ ATDC pre-injection starting instant. This injection pattern leads to increases in $6.7 \%$ in SFC, 3.47\% in CO and 3.83\% in $\mathrm{HC}$ but reduces $\mathrm{NO}_{\mathrm{x}}$ by $34.67 \%$ in comparison with the case without pre-injection. Future works will focus on analyzing other parameters such as number of pre-injections, dwelling time and injection angle, as well as other engines.

Author Contributions: Conceptualization, M.I.L.G. and C.G.R.V.; methodology, M.I.L.G. and C.G.R.V.; software, M.I.L.G. and C.G.R.V.; validation, M.I.L.G. and C.G.R.V.; formal analysis, M.I.L.G. and L.C.-S.; investigation, M.I.L.G. and C.G.R.V.; resources, M.I.L.G. and C.G.R.V.; writing-original draft preparation, M.I.L.G. and L.C.-S.; writing - review and editing, M.I.L.G. and L.C.-S. All authors have read and agreed to the published version of the manuscript.

Funding: This research received no external funding.

Acknowledgments: The authors would like to express their gratitude to Norplan Engineering S.L. and recommend the courses "CFD with OpenFOAM" and "C ++ applied to OpenFOAM" available at www.technicalcourses.net.

Conflicts of Interest: The authors declare no conflict of interest.

\section{Appendix A}

Table A1 lists the results of the 125 cases analyzed by the MCDM approach developed in the present work. Five pre-injection starting instants are included: $-22^{\circ}$ CA ATDC (Crank Angle After Top Dead Center),$-21^{\circ} \mathrm{CA}$ ATDC, $-20^{\circ} \mathrm{CA}$ ATDC, $-19^{\circ} \mathrm{CA}$ ATDC, and $-18^{\circ}$ CA ATDC; five pre-injection rates: $5 \%, 10 \%, 15 \%, 20 \%$, and $25 \%$; and five pre-injection durations: $1^{\circ} \mathrm{CA}$ (Crank Angle), $2^{\circ} \mathrm{CA}$, $3^{\circ} \mathrm{CA}, 4^{\circ} \mathrm{CA}$, and $5^{\circ} \mathrm{CA}$. Table $\mathrm{A} 1$ also includes the variation of SFC, $\mathrm{NO}_{\mathrm{x}}, \mathrm{CO}$ and $\mathrm{HC}$ in per unit basis, as well as the $A I$ obtained for each case analyzed. The minimum $A I$, which represents the most adequate solution, is highlighted. As can be seen, this minimum value was obtained for the 91th case, corresponding to $-19^{\circ} \mathrm{CA}$ ATDC pre-injection starting instant, $20 \%$ pre-injection rate, and $1^{\circ} \mathrm{CA}$ pre-injection duration, leading to variations of 0.067 in SFC, -0.3467 in $\mathrm{NO}_{\mathrm{x}}, 0.0347$ in $\mathrm{CO}$ and 0.0383 
in $\mathrm{HC}$. In a per cent basis, these values correspond to a $\mathrm{SFC}$ increment of $6,7 \%, \mathrm{NO}_{\mathrm{x}}$ reduction of $34.7 \%$, $\mathrm{CO}$ increment of $3.47 \%$, and $\mathrm{HC}$ increment of $3.83 \%$ in comparison with the case without pre-injection.

Table A1. Results of the 125 cases analyzed.

\begin{tabular}{|c|c|c|c|c|c|c|c|c|}
\hline Case & S ( ${ }^{\circ} \mathrm{CA}$ ATDC) & R (\%) & $\mathrm{D}\left({ }^{\circ} \mathrm{CA}\right)$ & SFC (-) & $\mathrm{NO}_{\mathbf{x}}(-)$ & $\mathrm{CO}(-)$ & HC (-) & AI (-) \\
\hline 1 & -22 & 5 & 1 & 0.1099 & -0.4455 & 0.0338 & 0.0393 & -0.0072 \\
\hline 2 & -22 & 5 & 2 & 0.0987 & -0.4111 & 0.0385 & 0.0426 & -0.0058 \\
\hline 3 & -22 & 5 & 3 & 0.0902 & -0.3846 & 0.0446 & 0.0474 & -0.0037 \\
\hline 4 & -22 & 5 & 4 & 0.0846 & -0.3659 & 0.0523 & 0.0538 & -0.0011 \\
\hline 5 & -22 & 5 & 5 & 0.0818 & -0.3551 & 0.0613 & 0.0619 & 0.0022 \\
\hline 6 & -22 & 10 & 1 & 0.1421 & -0.5484 & 0.0450 & 0.0514 & -0.0045 \\
\hline 7 & -22 & 10 & 2 & 0.1275 & -0.5061 & 0.0510 & 0.0555 & -0.0030 \\
\hline 8 & -22 & 10 & 3 & 0.1166 & -0.4735 & 0.0590 & 0.0618 & -0.0006 \\
\hline 9 & -22 & 10 & 4 & 0.1094 & -0.4505 & 0.0688 & 0.0701 & 0.0027 \\
\hline 10 & -22 & 10 & 5 & 0.1058 & -0.4371 & 0.0806 & 0.0805 & 0.0068 \\
\hline 11 & -22 & 15 & 1 & 0.1650 & -0.6194 & 0.0530 & 0.0600 & -0.0020 \\
\hline 12 & -22 & 15 & 2 & 0.1481 & -0.5716 & 0.0600 & 0.0648 & -0.0005 \\
\hline 13 & -22 & 15 & 3 & 0.1355 & -0.5347 & 0.0693 & 0.0721 & 0.0020 \\
\hline 14 & -22 & 15 & 4 & 0.1271 & -0.5087 & 0.0807 & 0.0817 & 0.0057 \\
\hline 15 & -22 & 15 & 5 & 0.1229 & -0.4937 & 0.0943 & 0.0938 & 0.0104 \\
\hline 16 & -22 & 20 & 1 & 0.1836 & -0.6752 & 0.0595 & 0.0669 & 0.0001 \\
\hline 17 & -22 & 20 & 2 & 0.1648 & -0.6231 & 0.0673 & 0.0723 & 0.0016 \\
\hline 18 & -22 & 20 & 3 & 0.1507 & -0.5829 & 0.0775 & 0.0804 & 0.0044 \\
\hline 19 & -22 & 20 & 4 & 0.1413 & -0.5546 & 0.0902 & 0.0911 & 0.0083 \\
\hline 20 & -22 & 20 & 5 & 0.1367 & -0.5382 & 0.1054 & 0.1045 & 0.0135 \\
\hline 21 & -22 & 25 & 1 & 0.1994 & -0.7219 & 0.0650 & 0.0728 & 0.0021 \\
\hline 22 & -22 & 25 & 2 & 0.1790 & -0.6662 & 0.0734 & 0.0787 & 0.0036 \\
\hline 23 & -22 & 25 & 3 & 0.1637 & -0.6232 & 0.0846 & 0.0874 & 0.0065 \\
\hline 24 & -22 & 25 & 4 & 0.1535 & -0.5930 & 0.0984 & 0.0991 & 0.0107 \\
\hline 25 & -22 & 25 & 5 & 0.1485 & -0.5755 & 0.1149 & 0.1137 & 0.0163 \\
\hline 26 & -21 & 5 & 1 & 0.0770 & -0.3497 & 0.0276 & 0.0326 & -0.0098 \\
\hline 27 & -21 & 5 & 2 & 0.0658 & -0.3153 & 0.0323 & 0.0358 & -0.0084 \\
\hline 28 & -21 & 5 & 3 & 0.0573 & -0.2888 & 0.0384 & 0.0407 & -0.0064 \\
\hline 29 & -21 & 5 & 4 & 0.0517 & -0.2701 & 0.0460 & 0.0471 & -0.0037 \\
\hline 30 & -21 & 5 & 5 & 0.0489 & -0.2593 & 0.0551 & 0.0551 & -0.0004 \\
\hline 31 & -21 & 10 & 1 & 0.0995 & -0.4305 & 0.0370 & 0.0427 & -0.0088 \\
\hline 32 & -21 & 10 & 2 & 0.0850 & -0.3882 & 0.0430 & 0.0469 & -0.0073 \\
\hline 33 & -21 & 10 & 3 & 0.0741 & -0.3555 & 0.0509 & 0.0531 & -0.0050 \\
\hline 34 & -21 & 10 & 4 & 0.0668 & -0.3325 & 0.0608 & 0.0614 & -0.0017 \\
\hline 35 & -21 & 10 & 5 & 0.0633 & -0.3192 & 0.0725 & 0.0718 & 0.0024 \\
\hline 36 & -21 & 15 & 1 & 0.1156 & -0.4862 & 0.0437 & 0.0499 & -0.0077 \\
\hline 37 & -21 & 15 & 2 & 0.0987 & -0.4384 & 0.0507 & 0.0547 & -0.0062 \\
\hline 38 & -21 & 15 & 3 & 0.0861 & -0.4015 & 0.0599 & 0.0620 & -0.0037 \\
\hline 39 & -21 & 15 & 4 & 0.0777 & -0.3755 & 0.0713 & 0.0716 & 0.0000 \\
\hline 40 & -21 & 15 & 5 & 0.0735 & -0.3605 & 0.0850 & 0.0837 & 0.0047 \\
\hline 41 & -21 & 20 & 1 & 0.1286 & -0.5300 & 0.0491 & 0.0557 & -0.0067 \\
\hline 42 & -21 & 20 & 2 & 0.1098 & -0.4779 & 0.0569 & 0.0611 & -0.0052 \\
\hline 43 & -21 & 20 & 3 & 0.0957 & -0.4377 & 0.0671 & 0.0691 & -0.0025 \\
\hline 44 & -21 & 20 & 4 & 0.0864 & -0.4094 & 0.0798 & 0.0799 & 0.0015 \\
\hline 45 & -21 & 20 & 5 & 0.0817 & -0.3930 & 0.0950 & 0.0933 & 0.0067 \\
\hline 46 & -21 & 25 & 1 & 0.1397 & -0.5667 & 0.0537 & 0.0607 & -0.0057 \\
\hline 47 & -21 & 25 & 2 & 0.1193 & -0.5110 & 0.0621 & 0.0665 & -0.0042 \\
\hline 48 & -21 & 25 & 3 & 0.1040 & -0.4680 & 0.0733 & 0.0753 & -0.0014 \\
\hline 49 & -21 & 25 & 4 & 0.0938 & -0.4377 & 0.0871 & 0.0869 & 0.0029 \\
\hline 50 & -21 & 25 & 5 & 0.0888 & -0.4202 & 0.1036 & 0.1015 & 0.0085 \\
\hline 51 & -20 & 5 & 1 & 0.0537 & -0.2774 & 0.0227 & 0.0269 & -0.0112 \\
\hline 52 & -20 & 5 & 2 & 0.0425 & -0.2431 & 0.0273 & 0.0301 & -0.0098 \\
\hline 53 & -20 & 5 & 3 & 0.0341 & -0.2165 & 0.0335 & 0.0350 & -0.0077 \\
\hline 54 & -20 & 5 & 4 & 0.0285 & -0.1979 & 0.0411 & 0.0414 & -0.0050 \\
\hline 55 & -20 & 5 & 5 & 0.0257 & -0.1870 & 0.0502 & 0.0494 & -0.0018 \\
\hline 56 & -20 & 10 & 1 & 0.0695 & -0.3416 & 0.0306 & 0.0353 & -0.0113 \\
\hline 57 & -20 & 10 & 2 & 0.0549 & -0.2992 & 0.0366 & 0.0395 & -0.0098 \\
\hline 58 & -20 & 10 & 3 & 0.0440 & -0.2666 & 0.0445 & 0.0457 & -0.0074 \\
\hline 59 & -20 & 10 & 4 & 0.0368 & -0.2436 & 0.0544 & 0.0540 & -0.0042 \\
\hline 60 & -20 & 10 & 5 & 0.0332 & -0.2303 & 0.0661 & 0.0644 & -0.0001 \\
\hline 61 & -20 & 15 & 1 & 0.0807 & -0.3857 & 0.0362 & 0.0413 & -0.0111 \\
\hline 62 & -20 & 15 & 2 & 0.0638 & -0.3379 & 0.0432 & 0.0462 & -0.0096 \\
\hline 63 & -20 & 15 & 3 & 0.0511 & -0.3011 & 0.0525 & 0.0534 & -0.0070 \\
\hline 64 & -20 & 15 & 4 & 0.0427 & -0.2751 & 0.0639 & 0.0631 & -0.0034 \\
\hline 65 & -20 & 15 & 5 & 0.0386 & -0.2601 & 0.0775 & 0.0751 & 0.0013 \\
\hline 66 & -20 & 20 & 1 & 0.0898 & -0.4205 & 0.0408 & 0.0462 & -0.0108 \\
\hline
\end{tabular}


Table A1. Cont.

\begin{tabular}{|c|c|c|c|c|c|c|c|c|}
\hline Case & $\mathrm{S}\left({ }^{\circ} \mathrm{CA}\right.$ ATDC) & R (\%) & $\mathrm{D}\left({ }^{\circ} \mathrm{CA}\right)$ & SFC (-) & $\mathrm{NO}_{\mathrm{x}}(-)$ & $\mathrm{CO}(-)$ & HC (-) & AI (-) \\
\hline 67 & -20 & 20 & 2 & 0.0710 & -0.3684 & 0.0486 & 0.0516 & -0.0093 \\
\hline 68 & -20 & 20 & 3 & 0.0569 & -0.3282 & 0.0589 & 0.0596 & -0.0066 \\
\hline 69 & -20 & 20 & 4 & 0.0475 & -0.2999 & 0.0716 & 0.0704 & -0.0026 \\
\hline 70 & -20 & 20 & 5 & 0.0429 & -0.2835 & 0.0868 & 0.0838 & 0.0026 \\
\hline 71 & -20 & 25 & 1 & 0.0975 & -0.4496 & 0.0447 & 0.0503 & -0.0105 \\
\hline 72 & -20 & 25 & 2 & 0.0771 & -0.3939 & 0.0532 & 0.0561 & -0.0090 \\
\hline 73 & -20 & 25 & 3 & 0.0618 & -0.3509 & 0.0643 & 0.0649 & -0.0061 \\
\hline 74 & -20 & 25 & 4 & 0.0516 & -0.3207 & 0.0781 & 0.0766 & -0.0019 \\
\hline 75 & -20 & 25 & 5 & 0.0466 & -0.3031 & 0.0946 & 0.0911 & 0.0037 \\
\hline 76 & -19 & 5 & 1 & 0.0401 & -0.2287 & 0.0190 & 0.0222 & -0.0113 \\
\hline 77 & -19 & 5 & 2 & 0.0289 & -0.1944 & 0.0237 & 0.0254 & -0.0098 \\
\hline 78 & -19 & 5 & 3 & 0.0204 & -0.1678 & 0.0298 & 0.0303 & -0.0078 \\
\hline 79 & -19 & 5 & 4 & 0.0148 & -0.1492 & 0.0374 & 0.0367 & -0.0051 \\
\hline 80 & -19 & 5 & 5 & 0.0121 & -0.1384 & 0.0465 & 0.0447 & -0.0018 \\
\hline 81 & -19 & 10 & 1 & 0.0519 & -0.2816 & 0.0258 & 0.0292 & -0.0119 \\
\hline 82 & -19 & 10 & 2 & 0.0373 & -0.2393 & 0.0319 & 0.0334 & -0.0104 \\
\hline 83 & -19 & 10 & 3 & 0.0264 & -0.2066 & 0.0398 & 0.0396 & -0.0080 \\
\hline 84 & -19 & 10 & 4 & 0.0192 & -0.1837 & 0.0497 & 0.0479 & -0.0048 \\
\hline 85 & -19 & 10 & 5 & 0.0156 & -0.1703 & 0.0614 & 0.0583 & -0.0007 \\
\hline 86 & -19 & 15 & 1 & 0.0602 & -0.3180 & 0.0308 & 0.0343 & -0.0121 \\
\hline 87 & -19 & 15 & 2 & 0.0433 & -0.2703 & 0.0378 & 0.0391 & -0.0106 \\
\hline 88 & -19 & 15 & 3 & 0.0307 & -0.2334 & 0.0470 & 0.0463 & -0.0080 \\
\hline 89 & -19 & 15 & 4 & 0.0223 & -0.2074 & 0.0584 & 0.0560 & -0.0044 \\
\hline 90 & -19 & 15 & 5 & 0.0181 & -0.1924 & 0.0721 & 0.0681 & 0.0003 \\
\hline 91 & -19 & 20 & 1 & 0.0670 & -0.3467 & 0.0347 & 0.0383 & -0.0122 \\
\hline 92 & -19 & 20 & 2 & 0.0482 & -0.2946 & 0.0425 & 0.0437 & -0.0107 \\
\hline 93 & -19 & 20 & 3 & 0.0341 & -0.2544 & 0.0528 & 0.0518 & -0.0080 \\
\hline 94 & -19 & 20 & 4 & 0.0248 & -0.2261 & 0.0655 & 0.0625 & -0.0040 \\
\hline 95 & -19 & 20 & 5 & 0.0201 & -0.2097 & 0.0807 & 0.0759 & 0.0012 \\
\hline 96 & -19 & 25 & 1 & 0.0728 & -0.3707 & 0.0381 & 0.0418 & -0.0122 \\
\hline 97 & -19 & 25 & 2 & 0.0524 & -0.3150 & 0.0465 & 0.0476 & -0.0107 \\
\hline 98 & -19 & 25 & 3 & 0.0371 & -0.2720 & 0.0577 & 0.0564 & -0.0079 \\
\hline 99 & -19 & 25 & 4 & 0.0269 & -0.2418 & 0.0715 & 0.0680 & -0.0036 \\
\hline 100 & -19 & 25 & 5 & 0.0219 & -0.2242 & 0.0880 & 0.0826 & 0.0020 \\
\hline 101 & -18 & 5 & 1 & 0.0361 & -0.2036 & 0.0166 & 0.0185 & -0.0101 \\
\hline 102 & -18 & 5 & 2 & 0.0249 & -0.1692 & 0.0213 & 0.0217 & -0.0086 \\
\hline 103 & -18 & 5 & 3 & 0.0164 & -0.1427 & 0.0274 & 0.0266 & -0.0066 \\
\hline 104 & -18 & 5 & 4 & 0.0108 & -0.1241 & 0.0351 & 0.0330 & -0.0039 \\
\hline 105 & -18 & 5 & 5 & 0.0081 & -0.1132 & 0.0441 & 0.0410 & -0.0007 \\
\hline 106 & -18 & 10 & 1 & 0.0467 & -0.2507 & 0.0228 & 0.0245 & -0.0106 \\
\hline 107 & -18 & 10 & 2 & 0.0322 & -0.2084 & 0.0288 & 0.0286 & -0.0091 \\
\hline 108 & -18 & 10 & 3 & 0.0213 & -0.1757 & 0.0368 & 0.0349 & -0.0068 \\
\hline 109 & -18 & 10 & 4 & 0.0140 & -0.1527 & 0.0466 & 0.0432 & -0.0035 \\
\hline 110 & -18 & 10 & 5 & 0.0104 & -0.1394 & 0.0583 & 0.0536 & 0.0006 \\
\hline 111 & -18 & 15 & 1 & 0.0543 & -0.2831 & 0.0272 & 0.0287 & -0.0108 \\
\hline 112 & -18 & 15 & 2 & 0.0374 & -0.2353 & 0.0342 & 0.0336 & -0.0093 \\
\hline 113 & -18 & 15 & 3 & 0.0247 & -0.1984 & 0.0434 & 0.0408 & -0.0067 \\
\hline 114 & -18 & 15 & 4 & 0.0163 & -0.1725 & 0.0549 & 0.0505 & -0.0031 \\
\hline 115 & -18 & 15 & 5 & 0.0121 & -0.1574 & 0.0685 & 0.0625 & 0.0016 \\
\hline 116 & -18 & 20 & 1 & 0.0604 & -0.3086 & 0.0308 & 0.0322 & -0.0109 \\
\hline 117 & -18 & 20 & 2 & 0.0416 & -0.2565 & 0.0386 & 0.0375 & -0.0094 \\
\hline 118 & -18 & 20 & 3 & 0.0275 & -0.2163 & 0.0488 & 0.0456 & -0.0066 \\
\hline 119 & -18 & 20 & 4 & 0.0181 & -0.1880 & 0.0615 & 0.0563 & -0.0027 \\
\hline 120 & -18 & 20 & 5 & 0.0135 & -0.1716 & 0.0767 & 0.0697 & 0.0025 \\
\hline 121 & -18 & 25 & 1 & 0.0656 & -0.3300 & 0.0338 & 0.0351 & -0.0108 \\
\hline 122 & -18 & 25 & 2 & 0.0451 & -0.2743 & 0.0423 & 0.0409 & -0.0094 \\
\hline 123 & -18 & 25 & 3 & 0.0298 & -0.2313 & 0.0534 & 0.0497 & -0.0065 \\
\hline 124 & -18 & 25 & 4 & 0.0197 & -0.2010 & 0.0672 & 0.0613 & -0.0023 \\
\hline 125 & -18 & 25 & 5 & 0.0146 & -0.1835 & 0.0837 & 0.0759 & 0.0033 \\
\hline
\end{tabular}

\section{References}

1. Shen, H.; Zhang, J.; Yang, B.; Jia, B. Development of a marine two-stroke diesel engine MVEM with in-cylinder pressure predictive capability and a novel compressor model. J. Mar. Sci. Eng. 2020, 8, 204. [CrossRef]

2. Sencic, T.; Mrzljak, V.; Blecich, P.; Bonefacic, I. 2D CFD simulation of water injection strategies in a large marine engine. J. Mar. Sci. Eng. 2019, 7, 296. [CrossRef] 
3. Sinay, J.; Puskar, M.; Kopas, M. Reduction of the NOx emissions in vehicle diesel engine in order to fulfill future rules concerning emissions released into air. Sci. Total Environ. 2018, 624, 1421-1428. [CrossRef] [PubMed]

4. Lamas, M.I.; Rodriguez, C.G. Emissions from marine engines and NOx reduction methods. J. Marit. Res. 2012, 9, 77-82.

5. di Sarli, V.; di Benedetto, A. Using CFD simulation as a tool to identify optimal operating conditions for regeneration of a catalytic diesel particulate filter. Appl. Sci. 2019, 9, 3453. [CrossRef]

6. Lamas, M.I.; Rodriguez, C.G. NOx reduction in diesel-hydrogen engines using different strategies of ammonia injection. Energies 2019, 12, 1255. [CrossRef]

7. Lamas, M.I.; Rodriguez, C.G. Numerical model to analyze NOx reduction by ammonia injection in diesel-hydrogen engines. Int. J. Hydrog. Energy 2017, 42, 26132-26141. [CrossRef]

8. Leach, F.; Ismail, R.; Davy, M. Engine-out emissions from a modern high speed diesel engine-The importance of nozzle tip protrusion. Appl. Energy 2018, 226, 340-352. [CrossRef]

9. Gao, Z.; Schreiber, W. The effects of EGR and split fuel injection on diesel engine emission. Int. J. Automot. Technol. 2001, 2, 123-133.

10. Park, S.W.; Suh, H.K.; Lee, C.S. Effects of a split injection on spray characteristics for a common-rail type diesel injection system. Int. J. Automot. Technol. 2005, 6, 315-322.

11. Chen, S.K. Simultaneous Reduction of NOx and Particulate Emissions by Using Multiple Injections in a Small Diesel Engine; SAE Technical Paper 2000-01-3084; SAE International: Warrendale, PA, USA, 2000. [CrossRef]

12. Shundoh, S.; Komori, M.; Tsujimura, K.; Kobayashi, S. NOx Reduction from Diesel Combustion Using Pilot Injection with High Pressure Fuel Injection; SAE Technical Paper 920461; SAE International: Warrendale, PA, USA, 1992. [CrossRef]

13. Carlucci, P.; Ficarella, A.; Laforgia, D. Effects of Pilot Injection Parameters on Combustion for Common Rail Diesel Engines; SAE Technical Paper 2003-01-0700; SAE International: Warrendale, PA, USA, 2003. [CrossRef]

14. Tanaka, T.; Ando, A.; Ishizaka, K. Study on pilot injection of DI diesel engine using common rail injection system. JSAE Rev. 2002, 23, 297-302. [CrossRef]

15. Benajes, J.; Molina, S.; Novella, R.; DeRudder, K. Influence of injection conditions and exhaust gas recirculation in a high-speed direct-injection diesel engine operating with a late split injection. Proc. Inst. Mech. Eng. Partd: J. Automob. Eng. 2008, 222, 629-641. [CrossRef]

16. Pierpont, D.; Montgomery, D.; Reitz, R. Reducing Particulate and NOx Using Multiple Injections and EGR in a DI Diesel; SAE Technical Paper 950217; SAE International: Warrendale, PA, USA, 1995. [CrossRef]

17. Hotta, Y.; Inayoshi, M.; Nakakita, K.; Fujiwara, K. Achieving Lower Exhaust Emissions and Better Performance in an HSDI Diesel Engine with Multiple Injection; SAE Technical Paper 2005-01-0928; SAE International: Warrendale, PA, USA, 2005. [CrossRef]

18. Fang, T.; Coverdill, R.; Lee, C.F.; White, R.A. Effects of injection angles on combustion process using multiple injection strategies in an HSDI diesel engine. Fuel 2008, 87, 3232-3239. [CrossRef]

19. Ishida, M.; Chen, Z.L.; Luo, G.F.; Ueki, H. The Effect of Pilot Injection on Combustion in a Turbocharged D. I. Diesel Engine; SAE Technical Paper 941692; SAE International: Warrendale, PA, USA, 1994. [CrossRef]

20. Minami, T.; Takeuchi, K.; Shimazaki, N. Reduction of Diesel Engine NOx Using Pilot Injection; SAE Techical Paper 950611; SAE International: Warrendale, PA, USA, 1995. [CrossRef]

21. Dhar, A.; Agarwal, A.K. Experimental investigations of the effect of pilot injection on performance, emissions and combustion characteristics of Karanja biodiesel fuelled CRDI engine. Energy Convers. Manag. 2015, 93, 357-366. [CrossRef]

22. Puskar, M.; Bigos, P. Output performance increase of two-stroke combustion engine with detonation combustion optimization. Strojarstvo 2010, 52, 577-587.

23. Puskar, M.; Brestovic, T.; Jasminska, N. Numerical simulation and experimental analysis of acoustic wave influences on brake mean effective pressure in thrust-ejector inlet pipe of combustion engine. Int. J. Veh. Des. 2015, 67, 63-76. [CrossRef]

24. Hunicz, J.; Geca, M.S.; Kordos, P.; Komsta, H. An experimental study on a boosted gasoline HCCI engine under different direct fuel injection strategies. Exp. Therm. Fluid Sci. 2015, 62, 151-163. [CrossRef]

25. Alla, G.H.A.; Soliman, H.A.; Badr, O.A. Effect of injection timing on the performance of a dual fuel engine. Energy Convers. Manag. 2002, 43, 269-277. [CrossRef] 
26. Papagiannakis, R.G.; Hountalas, D.T.; Rakopoulos, C.D. Theoretical study of the effects of pilot fuel quantity and its injection timing on the performance and emissions of a dual fuel diesel engine. Energy Convers. Manag. 2007, 48, 2951-2961. [CrossRef]

27. Ryu, K. Effects of pilot injection timing on the combustion and emissions characteristics in a diesel engine using biodiesel-CNG dual fuel. Appl. Energy 2013, 111, 721-730. [CrossRef]

28. Yang, B.; Wang, L.; Ning, L.; Zeng, K. Effects of pilot injection timing on the combustion noise and particle emissions of a diesel/natural gas dual-fuel engine at low load. Appl. Therm. Eng. 2016, 102, 822-828. [CrossRef]

29. Seddiek, I.S.; Elgohary, M.M.; Ammar, N. The hydrogen-fuelled internal combustion engines for marine applications with a case study. Brodogradnja 2015, 66, 23-38.

30. Carlucci, A.P.; Ficarella, A.; Laforgia, D. Control of the combustion behaviour in a diesel engine using early injection and gas addition. Appl. Therm. Eng. 2006, 26, 2279-2286. [CrossRef]

31. Hwang, J.; Qi, D.; Jung, Y.; Bae, C. Effect of injection parameters on the combustion and emission characteristics in a common-rail direct injection diesel engine fueled with waste cooking oil biodiesel. Renew. Energy 2014, 63, 9-17. [CrossRef]

32. Sinay, J.; Tompos, A.; Puskar, M.; Pctkova, V. Multiparametric diagnostics of gas engines. Trans. R. Inst. Nav. Archit. Part A: Int. J. Marit. Eng. 2014, 156, 149-156. [CrossRef]

33. Shi, J.; Wang, T.; Zhao, Z.; Yang, T.; Zhang, Z. Experimental study of injection parameters on the performance of a diesel engine with Fischer-Tropsch fuel synthesized from coal. Energies 2018, 11, 3280. [CrossRef]

34. di Sarli, V. Stability and emissions of a lean pre-mixed combustor with rich catalytic/lean-burn pilot. Int. J. Chem. React. Eng. 2014, 12, 77-89. [CrossRef]

35. Lechner, G.; Jacobs, T.; Chryssakis, C. Evaluation of a Narrow Spray Cone Angle, Advanced Injection Timing Strategy to Achieve Partially Premixed Compression Ignition Combustion in a Diesel Engine; SAE Technical Paper 2005-01-0167; SAE International: Warrendale, PA, USA, 2005. [CrossRef]

36. Sun, Y.; Reitz, R.D. Modeling Diesel Engine NOx and Soot Reduction with Optimized Two-Stage Combustion; SAE Technical Paper 2006-01-0027 2006; SAE International: Warrendale, PA, USA, 2006. [CrossRef]

37. Verbiezen, K.; Donkerbroek, A.J.; Klein-Douwel, R.J.H.; van Vliet, A.P.; Frijters, P.J.M.; Seykens, X.L.J. Diesel combustion: In-cylinder NO concentrations in relation to injection timing. Combust. Flame 2007, 151, 333-346. [CrossRef]

38. Zehni, A.; Jafarmadar, S. Multi-dimensional modeling of the effects of split injection scheme on combustion and emissions of direct-injection diesel engines at full load state. IJE Trans. 2009, 22, 369-378.

39. Abdullah, N.R.; Mamat, R.; Rounce, P.; Tsolakis, A.; Wyszynski, M.L.; Xu, H.M. Effect of Injection Pressure with Split Injection in a V6 Diesel Engine; SAE Technical Paper 2009-20-0049; SAE International: Warrendale, PA, USA, 2009; Volume 16, pp. 1-11. [CrossRef]

40. Coskun, G.; Soyhan, H.S.; Demir, U.; Turkcan, A.; Ozsezen, A.N.; Canakci, M. Influences of second injection variations on combustion and emissions of an HCCI-DI engine: Experiments and CFD modelling. Fuel 2014, 136, 287-294. [CrossRef]

41. Wang, X.; Zhao, H.; Xie, H. Effect of piston shapes and fuel injection strategies on stoichiometric stratified flame ignition (SFI) hybrid combustion in a PFI/DI gasoline engine by numerical simulations. Energy Convers. Manag. 2015, 98, 387-400. [CrossRef]

42. Zhaojie, S.; Cui, W.; Ju, X.; Liu, Z. Numerical investigation on effects of assigned EGR stratification on a heavy duty diesel engine with two-stage fuel injection. Energies 2018, 11, 515. [CrossRef]

43. Lamas, M.I.; de Dios Rodriguez, J.; Castro-Santos, L.; Carral, L.M. Effect of multiple injection strategies on emissions and performance in the Wärtsilä 6L 46 marine engine. A numerical approach. J. Clean. Prod. 2019, 206, 1-10. [CrossRef]

44. Lamas, M.I.; Rodriguez, C.G. Computational fluid dynamics analysis of the scavenging process in the MAN B\&W 7S50MC two-stroke diesel marine engine. J. Ship Res. 2012, 56, 154-161. [CrossRef]

45. Sencic, T. Analysis of soot and NOx emissions reduction possibilities on modern low speed, two-stroke, diesel engines. Strojarstvo 2010, 52, 525-533.

46. Ricart, L.M.; Xin, J.; Bower, G.R.; Reitz, R.D. In-Cylinder Measurement and Modeling of Liquid Fuel Spray Penetration in a Heavy-Duty Diesel Engine; SAE Technical Paper 971591; SAE International: Warrendale, PA, USA, 1997. [CrossRef] 
47. Dukowicz, J.K. A particle-fluid numerical model for liquid sprays. J. Comput. Phys. 1980, 35, $229-253$. [CrossRef]

48. Ra, Y.; Reitz, R. A reduced chemical kinetic model for IC engine combustion simulations with primary reference fuels. Combust. Flame 2008, 155, 713-738. [CrossRef]

49. Yang, H.; Krishnan, S.R.; Srinivasan, K.K.; Midkiff, K.C. Modeling of NOx emissions using a superextended Zeldovich mechanism. In Proceedings of the ICEF03 2003 Fall Technical Conference of the ASME Internal Combustion Engine Division, Erie, PA, USA, 7-10 September 2003.

50. Miller, J.A.; Glarborg, P. Modeling the formation of N2O and NO2 in the thermal DeNOx process. Springer Ser. Chem. Phys. 1996, 61, 318-333.

51. Lamas, M.I.; Rodríguez, C.G.; Rebollido, J.M. Numerical model to study the valve overlap period in the Wärtsilä 6L46 four-stroke marine engine. Pol. Marit. Res. 2012, 1, 31-37. [CrossRef]

52. Lamas, M.I.; Rodríguez, C.G. Numerical model to study the combustion process and emissions in the Wärtsilä 6L 46 four-stroke marine engine. Pol. Marit. Res. 2013, 20, 61-66. [CrossRef]

53. Galdo, M.I.L.; Castro-Santos, L.; Vidal, C.G.R. Numerical analysis of NOx reduction using ammonia injection and comparison with water injection. J. Mar. Sci. Eng. 2020, 8, 109. [CrossRef]

54. Lamas, M.I.; Rodriguez, C.G.; Telmo, J.; Rodriguez, J.D. Numerical analysis emissions from marine engines using alternative fuels. Pol. Marit. Res. 2015, 22, 48-52. [CrossRef]

55. Lamas, M.I.; Rodriguez, C.G.; Rodriguez, J.D.; Telmo, J. Internal modifications to reduce pollutant emissions from marine engines. A numerical approach. Int. J. Nav. Archit. Mar. Eng. 2013, 5, 493-501. [CrossRef]

56. Heywood, J. Internal Combustion Engine Fundamentals, 2nd ed.; McGraw-Hill Education: New York, NY, USA, 2018.

(C) 2020 by the authors. Licensee MDPI, Basel, Switzerland. This article is an open access article distributed under the terms and conditions of the Creative Commons Attribution (CC BY) license (http://creativecommons.org/licenses/by/4.0/). 